JOURNAL OF NURSING PRACTICE AND EDUCATION, VOL. 02 NO. 01, DESEMBER 2021

DOI:10.34305/jnpe.v2i1.337
Ciptaan disebarluaskan di bawah

Lisensi Creative Commons Atribusi- (c) (i)(2)

Non Komersial-Berbagi Serupa 4.0

\title{
HUBUNGAN ANTARA PENGETAHUAN DENGAN SIKAP IBU KADER TENTANG KANKER SERVIKS DI DESA DARMA KECAMATAN DARMA TAHUN 2018
}

\author{
Fera Riswidautami Herwandar, Reni Gustiawati \\ STIKes Kuningan \\ februari_rabu.fera88@yahoo.co.id
}

\begin{abstract}
Abstrak
Kanker serviks menempati posisi tertinggi sebagai penyakit kanker yang menyerang kaum perempuan. Indonesia didapatkan sebesar 1,4 per 1.000 penduduk serta merupakan penyebab kematian nomor 7 dari seluruh penyebab kematian. Tingginya angka kematian yang disebabkan kanker leher rahim dapat dicegah apabila wanita dewasa muda memiliki pengetahuan dan menyadari bahwa kanker leher rahim merupakan salah satu penyakit yang mematikan. Tujuan penelitian untuk mengetahui hubungan antara pengetahuan dengan sikap tentang pencegahan kanker serviks pada ibu kader di Desa Darma Kecamatan Darma Tahun 2018.Metode penelitian yang digunakan adalah survei analitik dengan rancangan cross sectional dengan menggunakan data primer, jumlah sampel sebanyak 30 responden, teknik pengambilan sampel total sampling yaitu seluruh ibu kader di Desa Darma Kecamatan Darma tahun 2018, analisa data menggunakan Spearman Rank. Hasil analisis univariat sebagian ibu kader memiliki pengetahuan baik sebanyak 46,7\% dan memiliki sikap baik sebanyak 58,7\%. Hasil analisis bivariat nilai $p=0,023$ dan nilai $r=0,415$. Hasil penelitian terdapat hubungan antara pengetahuan dengan sikap tentang pencegahan kanker serviks pada ibu kader di Desa Darma Kecamatan DarmaTahun 2018. Diharapkan ibu kader dapat membantu menyebarluaskan pengetahuan dan keterampilan yang mereka peroleh kepada masyarakat luas sehingga pengetahuan masyarakat tentang kanker leher rahim serta pencegahannya meningkat.
\end{abstract}

Kata kunci : Pencegahan Kanker Serviks

\section{Pendahuluan}

Salah satu penyakit kanker yang cukup banyak dijumpai pada kaum wanita adalah kanker servik. Kanker serviks atau kanker leher rahim atau disebut juga kanker mulut rahim merupakan salah satu penyakit keganasan di bidang kebidanan dan penyakit kandungan yang masih menempati posisi tertinggi sebagai penyakit kanker yang menyerang kaum perempuan 
JOURNAL OF NURSING PRACTICE AND EDUCATION, VOL. 02 NO. 01, DESEMBER 2021

DOI: $10.34305 /$ jnpe.v2i1.337

(Andrijono, 2008). Berdasarkan Data Badan Kesehatan Dunia, diketahui bahwa pada tahun 2012 kanker merupakan penyebab kematian nomor 2 setelah penyakit kardiovaskular (Emilia, 2013). Diperkirakan 7,5 juta orang meninggal akibat kanker, dan lebih dari 70\% kematian terjadi di negara miskindan berkembang. Jenis kanker tertinggi pada perempuan di dunia adalah kanker payudara (38 per 100.000 perempuan) dan kanker leher rahim (16 per 100.000 perempuan), sedangkan Indonesia didapatkan sebesar 1,4 per 1.000 penduduk serta merupakan penyebab kematian nomor $7(5,7 \%)$ dari seluruh penyebab kematian (Wahidin, 2015).

Menurut data Dinas Kesehatan Jawa Barat, pada tahun 2015 jumlah kanker serviks di daerah itu mencapai 1879 kasus yang terdiri atas 1185 orang menjalani rawat inap dan 694 orang rawat jalan, dengan demikian Provinsi Jawa Barat sebagai peringkat kedua kasus kanker serviks di tingkat nasional (Dinas Kesehatan Provinsi Jawa Barat, 2015). Berdasarkan data Dinkes Kuningan dari Januari 2015 sampai tanggal 21 Desember 2015 sebanyak 56 penderita kanker serviks (Dinas Kesehatan Kabupaten Kuningan, 2015). Desa Darma merupakan desa yang

\section{Ciptaan disebarluaskan di bawah Lisensi Creative Commons Atribusi- (c) (i)(2) \\ Non Komersial-Berbagi Serupa 4.0}

sangat bagus dalam melaksanakan kesehatan lingkungan namun kekurangan yang ada adalah kurangnya informasiinformasi kesehatan khususnya informasi tentang kanker serviks.

Berdasarkan berbagai survei diketahui bahwa salah satu faktor penyebab tingginya jumlah kasus kanker stadium lanjut adalah keengganan memeriksakan diri ke dokter karena takut didiagnosis kanker. Orang awam seringkali hanya mendengar bahwa kanker penyakit kutukan atau kanker tidak ada obatnya, tanpa pernah memperoleh informasi yang benar tentang kanker (Sabrida, 2015).

Tingginya angka kematian yang disebabkan kanker leher rahim dapat dicegah apabila wanita dewasa muda memiliki pengetahuan dan menyadari bahwa kanker leher rahim merupakan salah satu penyakit yang mematikan. Namun, dikarenakan oleh kurangnya pengetahuan mengenai kanker serviks sehingga wanita tidak merasa perlu untuk melakukan skrining (Anggraini, 2016).

Berdasarkan hasil penelitian Hidayati (2017) terdapat hubungan yang signifikan antara pengetahuan ibu tentang kanker serviks dengan perilaku pemeriksaan IVA. Begitu juga dengan hasil penelitian Masturoh(2016)terdapat 
JOURNAL OF NURSING PRACTICE AND EDUCATION, VOL. 02 NO. 01, DESEMBER 2021

DOI: $10.34305 /$ jnpe.v2i1.337

pengaruh antara sikap dengan perilaku WUS dalam melakukan pemeriksaan kanker serviks dengan menggunakan metode IVA.

Menurut Nurdiamah (2013)kader kesehatan diharapkan dapat membantu menyebarluaskan pengetahuan dan keterampilan yang mereka peroleh kepada masyarakat luas sehingga pengetahuan masyarakat tentang kanker leher rahim serta pencegahannya meningkat.

Data studi pendahuluan di Desa Darma kepada ibu kader melalui wawancara dengan menggunakan kuesioner sebanyak 10 pertanyaan kepada 10 responden didapatkan hasil bahwa 4 ibu kader berpengetahuan kurang, 3 ibu kader berpengetahuan cukup dan 3 ibu kader berpengetahuan baik. Dari $10 \mathrm{ibu}$ kader didapatkan hasil bahwa 4 ibu kader pernah melakukan pemeriksaan IVA dan 6 ibu kader mengatakan belum melakukan pemeriksaan IVA dikarenakan ada yang tidak tahu dan juga ada yang sudah mengetahui tentang pemeriksaan IVA tetapi tidak melakukan karena merasa malu, takut
Ciptaan disebarluaskan di bawah Lisensi Creative Commons Atribusi- (c) (i)(2)

Non Komersial-Berbagi Serupa 4.0

menerima hasilnya nanti dan ibu belum bisa memutuskan akan periksa atau tidak.

\section{Metode Penelitian}

Populasi adalah keseluruhan subjek penelitian Notoatmodjo (2012) . Populasi dalam penelitian ini adalah seluruh ibu kader di Desa Darma tahun 2018 sebanyak 30 responden. Pengambilan sampel dalam penelitian ini menggunakan teknik total sampling yaitu seluruh ibu kader di Desa Darma Kecamatan Darma tahun 2018 sebanyak 30 responden. Kuesioner tersebut didapat dari hasil penelitian Manurung(2016) sudah dilakukan uji validitas pada 20 sampel Wanita Usia Subur (WUS) dimodifikasi untuk kepentingan penelitian dengan tingkat kepercayaan 0,05 maka didapatkan nilai $r$ tabel $>0,444$. Berdasarkan hasil uji validitas didapatkan valid semua. Adapun hasil uji reliabilitas pengetahuan didapatkan 0,939 dan sikap didapatkan 0,940 sehingga item pertanyaan dapat dinyatakan akan sangat reliabel. 
JOURNAL OF NURSING PRACTICE AND EDUCATION, VOL. 02 NO. 01, DESEMBER 2021

DOI:10.34305/jnpe.v2i1.337
Ciptaan disebarluaskan di bawah Lisensi Creative Commons Atribusi- (c) (i)(2)

Non Komersial-Berbagi Serupa 4.0

\section{Hasil dan Pembahasan}

Analisis Univariat

Tabel 1.1 Distribusi Frekuensi Pengetahuan tentang Pencegahan Kanker Serviks pada Ibu Kader di Desa Darma Kecamatan Darma

\begin{tabular}{ccc}
\hline Pengetahuan & Frekuensi & Persentase (\%) \\
\hline Baik & 14 & 46,7 \\
Cukup & 11 & 36,6 \\
Kurang & 5 & 16,7 \\
Total & $\mathbf{3 0}$ & $\mathbf{1 0 0}$ \\
\hline
\end{tabular}

Sumber : Data Primer, 2018

Berdasarkan table 1.1 diketahui dari pengetahuan kurang sebanyak 5 responden 30 responden, yang memiliki pengetahuan $(16,7 \%)$.

baik sebanyak 14 responden $(46,7 \%)$ dan

Table 1.2 Distribusi Frekuensi Sikap tentang Pencegahan Kanker Serviks pada Ibu Kader di Desa Darma Kecamatan Darma Tahun 2018

\begin{tabular}{ccc}
\hline Sikap & Frekuensi & Presentase (\%) \\
\hline Baik & 25 & 83,3 \\
Buruk & 5 & 16,7 \\
Total & $\mathbf{3 0}$ & $\mathbf{1 0 0}$ \\
\hline
\end{tabular}

Sumber : Data Primer, 2018

Berdasarkan table 1.2 diketahui bahwa dari 30 responden, sebagian besar memiliki baik sebanyak 25 responden $(58,7 \%)$

\section{Analisis Bivarat}

Table 1.3 Hubungan antara Pengetahuan dengan Sikap tentang Pencegahan

Kanker Serviks pada Ibu Kader di Desa Darma Kecamatan Darma Tahun 2018

\begin{tabular}{|c|c|c|c|c|c|c|c|c|}
\hline \multirow{3}{*}{ PENGETAHUAN } & \multicolumn{4}{|c|}{ SIKAP } & \multirow{2}{*}{\multicolumn{2}{|c|}{ TOTAL }} & \multirow{3}{*}{ NILAI } & \multirow{3}{*}{ CORRELATION } \\
\hline & \multicolumn{2}{|c|}{ Baik } & \multicolumn{2}{|c|}{ Buruk } & & & & \\
\hline & $\mathbf{F}$ & $\%$ & $\mathbf{F}$ & $\%$ & $\mathbf{n}$ & $\%$ & & \\
\hline Baik & 14 & 100 & 0 & 0 & 14 & 100 & & \\
\hline Cukup & 11 & 100 & 0 & 0 & 11 & 100 & 0.023 & 0,415 \\
\hline Kurang & 0 & 0 & 5 & 100 & 5 & 100 & & \\
\hline
\end{tabular}

Sumber : Data Primer, 2018

Berdasarkan tabel 1.3 menunjukan bahwa dari 14 responden yang memiliki
Berikut ini merupakan table silang hubungan antara pengetahuan dengan sikap pencegahan kanker serviks pada Ibu Kader di Desa Darma Kecamatan Darma Tahun 2018. 
JOURNAL OF NURSING PRACTICE AND EDUCATION, VOL. 02 NO. 01, DESEMBER 2021

DOI:10.34305/jnpe.v2i1.337

dari 11 responden yang memiliki pengetahuan cukup seluruhnya memiliki sikap baik sebanyak 11 responden (100\%) dan dari 5 responden yang memiliki pengetahuan kurang seluruhnya memiliki sikap buruk sebanyak 5 responden (100\%). Hasil uji statistik dengan menggunakan Spearman's rank didapatkan nilai $\mathrm{p}$ value 0,023 jadi nilai $\mathrm{p}$ kurang dari $<0,05$ dengan demikian terdapat hubungan antara tingkat pengetahuan dengan sikap tentang pencegahan kanker serviks pada ibu kader di Desa Darma Kecamatan Darma Tahun 2018 dan nilai $r=0,415$ artinya memiliki kekuatan yang sedang. Berdasarkan hasil analisis diperoleh dari 30 responden yang memiliki pengetahuan baik lebih banyak daripada pengetahuan cukup dan kurang.

Menurut Masturoh (2016), pengetahuan yang baik seseorang akan mencari informasi tentang kesehatannya, terutama dalam hal pemeriksaan kanker leher rahim. Informasi yang diperoleh baik dari pendidikan formal maupun non formal dapat memberikan pengaruh jangka pendek (Immediate Impact).

Notoatmodjo (2013) mengatakan bahwa cara memelihara kesehatan, meliputi pengetahuan tentang penyakit menular dan tidak menular termasuk jenis penyakitnya, gejala dan tanda, cara

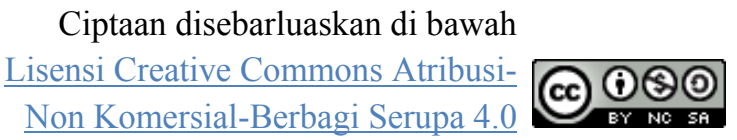

penularan, cara pencegahan dan bagaimana mengatasi penyakitnya : pengetahuan tentang faktor apa saja yang mempengaruhi dan mendukung kesehatan, seperti gizi dan nutrisi, sarana air bersih, kebersihan, polusi dan sebagainya; pengetahuan mengenai fasilitas pelayanan kesehatan dan pengetahuan mengenai upaya menghindari atau pencegahan terhadap kecelakaan.

Pengetahuan diperoleh berdasarkan pada kekuasaan, baik otoritas tradisi, otoritas pemerintah, otoritas pemimpin, maupun otoritas ahli ilmu pengetahuan. Sesuai dengan hasil penelitian Gustiana, (2014) terdapat 99 responden sebagian besar memiliki pengetahuan tinggi (baik) sebanyak 53 responden (53,5\%). Alasan peneliti, hal ini disebabkan oleh adanya informasi yang responden dapatkan. Berdasarkan hasil penelitian sebagian besar ibu kader memiliki pengetahuan baik, peneliti berasumsi hal ini disebabkan informasi yang ibu kader dapatkan. Hal ini terlihat dari hasil kuesioner pengetahuan nomor 17 didapatkan sebagian besar menjawab benar tentang cara melakukan deteksi dini kanker leher rahim. Mereka mengetahui bahwa cara melakukan deteksi dini diantaranya IVA dan pap smear. Berdasarkan informasi dari ibu kader yang 
JOURNAL OF NURSING PRACTICE AND EDUCATION, VOL. 02 NO. 01, DESEMBER 2021

DOI:10.34305/jnpe.v2i1.337

memiliki pengetahuan baik, informasi tersebut ibu dapatkan melalui televisi, internet, penyuluhan, disamping itu ada juga yang suka mengikuti pelatihan atau seminar tapi tidak semua dan itu pun ditentukan dan ditunjuk oleh pihak Desa sebagai perwakilan dari Desa tersebut, dengan demikian informasi mempunyai pengaruh terhadap pengetahuan seseorang. Meskipun demikian, didapatkan juga ibu kader yang memiliki pengetahuan cukup dan kurang, hal ini berkaitan dengan daya tangkap yang ibu kader terima, karena kemampuan seseorang dalam menerima informasi berbeda-beda. Berdasarkan hasil analisis diperoleh dari dari 30 responden yang memiliki sikap baik tentang pencegahan kanker serviks lebih banyak daripada yang memiliki sikap buruk.

Menurut Priyoto (2014), sikap adalah mekanisme mental yang mengevaluasi, membentuk pandangan, mewarnai perasaan, dan akan menentukan kecenderungan perilaku kita terhadap manusia atau sesuatu yang kita hadapi, bahkan terhadap diri kita sendiri.

Menurut Azwar (2013), salah satu faktor yang mempengaruhi sikap yaitu pengaruh orang yang dianggap penting. Lestari (2016) menambahkan bahwa sikap baik dimotivasi oleh keinginan untuk
Ciptaan disebarluaskan di bawah Lisensi Creative Commons Atribusi- (c) (i)(2)

Non Komersial-Berbagi Serupa 4.0

berafiliasi dan keinginan untuk menghindari konflik dengan orang yang dianggap penting tersebut. Sikap seseorang terhadap suatu objek menunjukkan pengetahuan orang tersebut terhadap objek yang bersangkutan.

Sesuai dengan hasil penelitian Anggraini (2016), dari 78 responden sebagian besar memiliki sikap mendukung (baik) sebanyak 46 responden (59\%). Alasan peneliti, hal ini disebabkan oleh adanya kesadaran responden untuk melakukan pencegahan kanker serviks.

Berdasarkan hasil penelitian, sebagian ibu kader memiliki sikap baik, peneliti berasumsi hal ini disebabkan oleh adanya kesadaran yang dimiliki ibu kader untuk bersikap baik. Ibu kader merupakan salah satu orang yang harus dijadikan contoh bagi orang lain, adanya kesadaran tersebut, mengakibatkan sikap ibu dijaga sebaik mungkin agar dapat membawa dampak baik bagi lingkungannya. Disamping itu, seringnya ibu mendapat bimbingan dari tenaga kesehatan, mengakibatkan ibu kader bersikap baik akibat dari pengetahuan yang ibu kader dapatkan. Hal ini terlihat dari hasil kuesioner sikap pada soal nomor 7, sebagian besar ibu kader menjawab setuju untuk segera melakukan pemeriksaan dini 
JOURNAL OF NURSING PRACTICE AND EDUCATION, VOL. 02 NO. 01, DESEMBER 2021

DOI:10.34305/jnpe.v2i1.337

kanker serviks apabila di Desa diadakan tes untuk pemeriksaan dini kanker serviks. Adanya rasa tanggung jawab yang tinggi sebagai seorang kader, mengakibatkan ibu bersikap baik agar orang lain dapat mengikutinya untuk melakukan deteksi dini kanker serviks.Berdasarkan hasil penelitian dengan menggunakan Spearman's rank didapatkan nilai $\mathrm{p}$ value 0,023 jadi nilai $\mathrm{p}$ kurang dari $<0,05$ dengan demikian terdapat hubungan antara tingkat pengetahuan dengan sikap tentang pencegahan kanker serviks pada ibu kader di Desa Darma Kecamatan Darma Tahun 2018 dan nilai $r=0,415$ artinya memiliki kekuatan yang sedang, dengan demikian masih ada faktor lain yang dapat mempengaruhi seseorang dalam melakukan pencegahan kanker serviks.

Hal ini sesuai dengan pendapat Budiman(2014), mengatakan bahwa perilaku yang didasari oleh pengetahuan akan lebih langgeng dari pada perilaku yang tidak didasari oleh pengetahuan. Masturoh (2016), mengatakan bahwa pengetahuan yang baik maka seseorang akan mencari informasi tentang kesehatannya, terutama dalam hal pemeriksaan kanker leher rahim. Sugiyono(2011), sikap yang baik menunjukkan atau memperlihatkan,

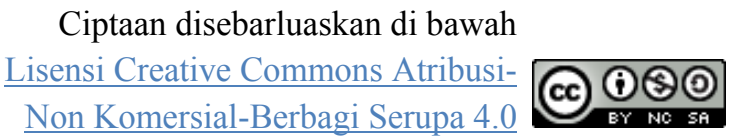

menerima, mengakui, menyetujui, serta melaksanakan norma-norma yang berlaku di mana individu itu berada. Menurut Wawan dan dewi, (2011) faktor-faktor yang mempengaruhi pengetahuan yaitu pendidikan, pekerjaan, umur, paritas, pengalaman, lingkungan, informasi, sosial budaya dan ekonomi, fasilitas dan penghasilan. Azwar(2013)menjelaskan bahwa faktor-faktor yang mempengaruhi sikap terhadap objek sikap antara lain pengalaman pribadi, pengaruh orang lain yang dianggap penting, pengaruh kebudayaan, media masa, lembaga pendidikan dan lembaga agama, faktor emosional dan pengetahuan.Sesuai dengan hasil penelitian Hidayati (2017) terdapat hubungan yang signifikan antara pengetahuan ibu tentang kanker serviks dengan perilaku pemeriksaan IVA. Begitu juga dengan hasil penelitian Masturoh(2016) terdapat pengaruh antara. Berdasarkan hasil penelitian sebagian besar ibu kader memiliki pengetahuan baik, peneliti berasumsi hal ini disebabkan informasi yang ibu kader dapatkan. Hal ini terlihat dari hasil kuesioner pengetahuan nomor 17 didapatkan sebagian besar menjawab benar tentang cara melakukan deteksi dini kanker leher rahim. Mereka mengetahui bahwa cara melakukan deteksi 
JOURNAL OF NURSING PRACTICE AND EDUCATION, VOL. 02 NO. 01, DESEMBER 2021

DOI:10.34305/jnpe.v2i1.337

dini diantaranya IVA dan pap smear. Berdasarkan informasi dari ibu kader yang memiliki pengetahuan baik, informasi tersebut ibu dapatkan melalui televisi, internet, penyuluhan, disamping itu ada juga yang suka mengikuti pelatihan atau seminar tapi tidak semua dan itu pun ditentukan dan ditunjuk oleh pihak Desa sebagai perwakilan dari Desa tersebut, dengan demikian informasi mempunyai pengaruh terhadap pengetahuan seseorang. Meskipun demikian, didapatkan juga ibu kader yang memiliki pengetahuan cukup dan kurang, hal ini berkaitan dengan daya tangkap yang ibu kader terima, karena kemampuan seseorang dalam menerima informasi berbeda-beda. Berdasarkan hasil analisis diperoleh dari dari 30 responden yang memiliki sikap baik tentang pencegahan kanker serviks lebih banyak daripada yang memiliki sikap buruk.

Menurut Priyoto(2014), sikap adalah mekanisme mental yang mengevaluasi, membentuk pandangan, mewarnai perasaan, dan akan menentukan kecenderungan perilaku kita terhadap manusia atau sesuatu yang kita hadapi, bahkan terhadap diri kita sendiri. Menurut Azwar(2013), salah satu faktor yang mempengaruhi sikap yaitu pengaruh orang yang dianggap penting. Lestari (2016), menambahkan bahwa sikap baik dimotivasi oleh keinginan untuk berafiliasi dan keinginan untuk menghindari konflik dengan orang yang dianggap penting tersebut. Sikap seseorang terhadap suatu objek menunjukkan pengetahuan orang tersebut terhadap objek yang bersangkutan.

Sesuai dengan hasil penelitian Anggraini (2016), dari 78 responden sebagian besar memiliki sikap mendukung (baik) sebanyak 46 responden (59\%). Alasan peneliti, hal ini disebabkan oleh adanya kesadaran responden untuk melakukan pencegahan kanker serviks.

Berdasarkan hasil penelitian, sebagian ibu kader memiliki sikap baik, peneliti berasumsi hal ini disebabkan oleh adanya kesadaran yang dimiliki ibu kader untuk bersikap baik. Ibu kader merupakan salah satu orang yang harus dijadikan contoh bagi orang lain, adanya kesadaran tersebut, mengakibatkan sikap ibu dijaga sebaik mungkin agar dapat membawa dampak baik bagi lingkungannya. Disamping itu, seringnya ibu mendapat bimbingan dari tenaga kesehatan, mengakibatkan ibu kader bersikap baik akibat dari pengetahuan yang ibu kader dapatkan. Hal ini terlihat dari hasil kuesioner sikap pada soal nomor 7, sebagian besar ibu kader menjawab setuju 
JOURNAL OF NURSING PRACTICE AND EDUCATION, VOL. 02 NO. 01, DESEMBER 2021

DOI:10.34305/jnpe.v2i1.337

untuk segera melakukan pemeriksaan dini kanker serviks apabila di Desa diadakan tes untuk pemeriksaan dini kanker serviks. Adanya rasa tanggung jawab yang tinggi sebagai seorang kader, mengakibatkan ibu bersikap baik agar orang lain dapat mengikutinya untuk melakukan deteksi dini kanker serviks.

Berdasarkan hasil penelitian dengan menggunakan Spearman's rank didapatkan nilai $p$ value 0,023 jadi nilai $p$ kurang dari $<0,05$ dengan demikian terdapat hubungan antara tingkat pengetahuan dengan sikap tentang pencegahan kanker serviks pada ibu kader di Desa Darma Kecamatan Darma Tahun 2018 dan nilai $\mathrm{r}=0,415$ artinya memiliki kekuatan yang sedang, dengan demikian masih ada faktor lain yang dapat mempengaruhi seseorang dalam melakukan pencegahan kanker serviks.

sikap dengan perilaku WUS dalam melakukan pemeriksaan kanker serviks dengan menggunakan metode IVA. Alasan peneliti adanya pengetahuan yang baik pada responden mengakibatkan sikap responden menjadi baik. Umur, pengalaman, pendidikan dan pekerjaan merupakan beberapa faktor yang mempengaruhi responden dalam melakukan pencegahan kanker serviks.

\section{Ciptaan disebarluaskan di bawah Lisensi Creative Commons Atribusi- (c) (i)(2) Non Komersial-Berbagi Serupa 4.0}

Berdasarkan hasil penelitian responden yang memiliki pengetahuan baik dan cukup seluruhnya bersikap baik tentang pencegahan kanker serviks, hal ini disebabkan oleh pengalaman yang ibu kader rasakan. Hal ini terlihat dari hasil kuesioner sikap pada soal nomor 3 didapatkan sebagian besar responden menjawab setuju jika menjalankan perilaku hidup bersih dan sehat dapat mencegah terjadinya kanker. Mereka merasakan sendiri, dengan perilaku hidup bersih dan sehat dapat menjadikan ibu menjadi sehat, disamping itu dengan seringnya mengikuti penyuluhan dalam bidang kesehatan, mengakibatkan ibu kader memahami bagaimana melakukan sikap yang baik agar dapat menjaga kesehatannya. Disamping itu, ibu berada di lingkungan yang mendukung dalam hal kesehatan, maka tidak menutup kemungkinan seseorang akan memperoleh pengetahuan yang baik dan dapat bersikap dengan baik terhadap pencegahan kanker serviks tersebut.

Faktor yang lainnya yang mengakibatkan ibu kader bersikap baik karena adanya kesadaran ibu kader terhadap kesehatan, kondisi tersebut disebabkan oleh adanya pengetahuan yang 
JOURNAL OF NURSING PRACTICE AND EDUCATION, VOL. 02 NO. 01, DESEMBER 2021

DOI:10.34305/jnpe.v2i1.337

ibu dapatkan baik dari tenaga kesehatan maupun dari media masa.

Hal ini terlihat dari hasil kuesioner pengetahuan pada soal nomor 19 sebagian besar responden menjawab benar tentang semua wanita yang sudah menikah atau $>$ 30 tahun dan sudah aktif melakukan hubungan seks dianjurkan untuk melakukan test IVA. Adanya kesadaran tersebut, ibu kader bersikap baik untuk melakukan deteksi dini sebagai pencegahan kanker serviks.

Selain itu adanya faktor ekonomis membuat ibu bersikap baik untuk melakukan pencegahan kanker serviks. Hal ini terlihat dari hasil kuesioner pengetahuan pada soal nomor 20 didapatkan sebagian besar responden menjawab benar tentang pemeriksaan Test IVA dapat dilakukan di Puskesmas, dengan mudahnya akses pemeriksaan dan harganya murah, mengakibatkan sebagian besar responden bersikap baik untuk melakukan pencegahan kanker serviks.

Adapun ibu kader yang memiliki pengetahuan kurang memiliki sikap buruk, hal ini disebabkan oleh adanya kurangnya pengetahuan ibu dan faktor emosional yang ibu kader rasakan. Sebenarnya ibu kader aktif mengikuti penyuluhan, akan tetapi karena adanya rasa takut dan malu
Ciptaan disebarluaskan di bawah

Lisensi Creative Commons Atribusi- (c) (i)(2)

Non Komersial-Berbagi Serupa 4.0

jika dilakukan pemeriksaan kanker serviks mengakibatkan responden bersikap buruk terhadap pencegahan kanker serviks tersebut. Hal ini terlihat dari hasil kuesioner sikap pada soal nomor 16, didapatkan banyak ibu kader yang setuju adanya rasa malu melakukan tes IVA atau papsmear karena harus memperlihatkan kemaluan ibu. Kondisi lain yaitu adanya lingkungan keluarga yang tidak mendukung untuk melakukan pemeriksaan kanker serviks. Hal ini terlihat dari hasil kuesioner sikap nomor 12 didapatkan sebagian besar ibu kader tidak setuju untuk melakukan pemeriksaan kanker serviks jika suami melarangnya. Mereka mengatakan bahwa istri harus tunduk pada suami, sehingga meskipun pencegahan kanker serviks merupakan sikap yang baik, akan kader sendiri tetapi jika tidak mendapatkan izin suami, maka ibu lebih baik tidak melakukannya.

Berdasarkan hasil penelitian dapat diketahui bahwa sikap ibu dalam melakukan pencegahan kanker serviks tidak hanya dipengaruhi oleh pengetahuan saja, akan tetapi dipengaruhi oleh faktor lain diantaranya pengalaman, lingkungan, informasi, sosial ekonomi dan kesadaran atau faktor emosional yang dimiliki ibu. Perlu adanya peningkatan pengetahuan dan 
JOURNAL OF NURSING PRACTICE AND EDUCATION, VOL. 02 NO. 01, DESEMBER 2021

DOI:10.34305/jnpe.v2i1.337

sikap yang baik pada ibu kader dengan cara membina hubungan baik antara tenaga kesehatan dengan ibu-ibu kader dengan melibatkan pula suami agar suami dapat mengetahui manfaat dilakukannya deteksi dini kanker serviks sebagai langkah awal pencegahan kanker serviks.

\section{Kesimpulan}

Berdasarkan hasil penelitian tentang hubungan antara pengetahuan dengan sikap tentang pencegahan kanker serviks pada ibu kader di Desa Darma Kecamatan Darma tahun 2018, maka penulis membuat kesimpulan sebagai berikut, Sebagian ibu kader di Desa Darma Kecamatan Darma Tahun 2018 memiliki pengetahuan baik sebanyak 46,7\%, Sebagian ibu kader di Desa Darma Kecamatan Darma Tahun 2018 memiliki sikap baik sebanyak 58,7\% dan terdapat hubungan antara pengetahuan dengan sikap tentang pencegahan kanker serviks

\section{Daftar Pustaka}

Andrijono. Kanker Serviks, Divisi Onkologi Departemen Obstetri Dan. Gynecolog. Jakarta: Fakultas Kedokteran Universitas Indonesia., 2008.

Anggraini. "Hubungan Pengetahuan Dan Sikap Wanita Pasangan Usia Suburdengan Deteksi Dini Ca Serviks

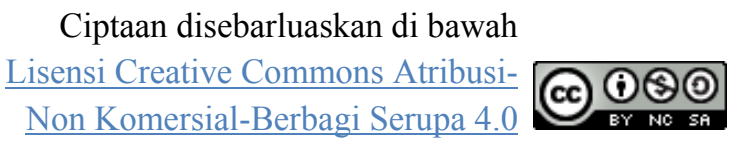

pada ibu kader di Desa Darma Kecamatan Darma Tahun 2018 dengan nilai $\mathrm{p}=0,023$ dan nilai $r=0,415$.

\section{Saran}

Bagi Ibu Kader Hasil penelitian ini diharapkan ibu kader dapat membantu menyebarluaskan pengetahuan dan keterampilan yang mereka peroleh kepada masyarakat luas sehingga pengetahuan masyarakat tentang kanker leher rahim serta pencegahannya meningkat. Bagi Desa Darma Diharapkan Desa Darma dapat meningkatkan wawasan dan pengetahuan masyarakat yang dimulai dari para kader agar dapat memotivasi warganya untuk melakukan deteksi dini berperilaku hidup sehat sebagai langkah awal pencegahan kanker serviks. Studi Diploma III Kebidanan STIKes Kuningan Hasil penelitian ini diharapkan dapat dijadikan sebagai tambahan referensi di perpustakaan dan penelitian lebih lanjut guna menjadi sumber pembelajaran.

Melalui Pap Smear Di Desa KetanenKabupaten Pati." Rakernas Aipkema 2016"Temu Ilmiah Hasil Penelitian Dan Pengabdian Masyarakat., 2016.

Azwar. Sikap Manusia Teori Dan Pengukurannya. Yogyakarta: Pelajar, 2013.

Budiman. Kapita Selekta Kuesioner Pengetahuan Dan Sikap Dalam 
JOURNAL OF NURSING PRACTICE AND EDUCATION, VOL. 02 NO. 01, DESEMBER 2021

DOI: 10.34305/jnpe.v2i1.337

Penelitian Kesehatan. Jakarta: Salemba Medika., 2014.

Dinas Kesehatan Kabupaten Kuningan. "Cakupan Deteksi Dini Kanker Rahim Dengan Metode IVA Dan Kanker Payudara Dengan Pemeriksaan Klinis (CBE) Menurut Kecamatan Dan Puskesmas Kabupaten Kuningan 2015,” 2015.

Dinas Kesehatan Provinsi Jawa Barat. Ringkasan Eksekutif Data Dan Informasi Kesehatan Provinsi Jawa Barat. Bandung: Pusat Data dan Informasi Kementerian Keseharan Republik Indonesia, 2015.

Emilia. Bebas Ancaman Kanker Serviks. Jakarta : Media Pressindo, 2013.

Gustiana. "Faktor-Faktor Yang Berhubungan Dengan Perilaku Pencegahan Kanker Serviks Pada Wanita Usia Subur." Jurnal Kesehatan PSIK Volume 1 Nomor 2 Oktober 2014, 2014.

Hidayati. "Hubungan Pengetahuan Dan Sikap IbuTentang Kanker Serviks DenganPerilaku Pemeriksaan IVAdi Puskesmas Mlati II." Naskah Publikasi, 2017.

Lestari. "Hubungan Pengetahuan Dan Sikap WUS Dengan Perilaku Melakukan Pemeriksaan IVA Di Kelurahan Kotabaru Wilayah Kerja Puskesmas Gondokusuman II Yogyakarta." Naskah Publikasi, 2016.

Manurung. "Hubungan Tingkat Pengetahuan Dan Sikap Deteksi Dini

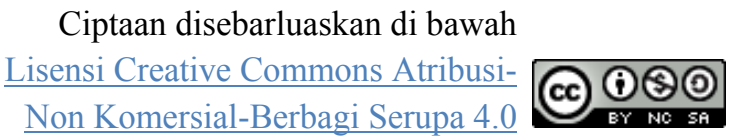

Kanker Leher Rahim Dengan Test IVA Pada Wanita Usia Subur (WUS) Di Wilayah Kerja Puskesmas Helvetia Kota Medan Tahun 2016." Skripsi, 2016. http://repository.usu.ac.id.

Masturoh, E. "Faktor-Faktor Yang Mempengaruhi Wanita Usia Subur (WUS) Dalam Melakukan Deteksi Dini Kanker Serviks Metode Inspeksi Visual Asam Asetat (IVA)." Skripsi, 2016.

http://lib.unnes.ac.id/26206/1/641141 2056.pdf.

Notoatmodjo, S. Metode Penelitian Kesehatan. Jakarta: Rineka Cipta, 2012.

Notoatmodjo, S. Promosi Kesehatan Dan Ilmu Perilaku. Jakarta: Rineka Cipta, 2013.

Priyoto. Teori Sikap Dan Perilaku Dalam Kesehatan. Yogyakarta: Nuha Medika., 2014.

Sabrida, H. Peranan Deteksi Dina Kanker Untuk Menurunkan Penyakit Kanker Stadium Lanjut Buletin Jurnal Data Dan Informasi Kesehatan. Jakarta, 2015.

Sugiyono. Metodologi Penelitian Pendidikan. Bandung: Alfabeta., 2011.

Wahidin. "Deteksi Dini Kanker Leher Rahim Dan Kanker Payudara Di Indonesia 2007-2014,”2015.

Wawan dan dewi. Teori Dan Pengukuran Pengetahuan Sikap Prilaku Manusia. Yogyakarta: Nuha, 2011. 